\title{
Analysis of the Utilization of Putri Cempo Landfill Waste for Power Plants and Their Effects on the Surakarta Electric Power Distribution Network
}

\author{
Slamet Suripto ${ }^{*}$, Rahmat Adiprasetya Al Hasibi ${ }^{1}$, Rama Okta Wiyagi ${ }^{1}$, Sanupal ${ }^{1}$, Yessi Jusman ${ }^{1}$, \\ Didik Aribowo ${ }^{2}$ \\ ${ }^{1}$ Department of Electrical Engineering, Universitas Muhammadiyah Yogyakarta \\ Jl. Brawijaya, Tamantirto, Kasihan, Yogyakarta, Indonesia \\ ${ }^{2}$ Vocational Education of Electrical Engineering Department, Universitas Sultan Ageng Tirtayasa \\ J1. Ciwaru Raya 25, Serang, Banten, Indonesia. \\ *Corresponding author, e-mail: slametsuripto@yahoo.com
}

\begin{abstract}
Growth in electric energy demand, domination of use of fossil fuels, and waste problems are fundamental to this research. The purpose of this research is to find out the electrical energy potential of the Putri Cempo Landfill waste, Surakarta. The potential of electrical energy is designed for waste power plant (WPP). Penetration of WPP as a Distributed Generation (DG) to the $20 \mathrm{kV}$ electrical distribution network is analyzed to determine its effect on the growth of demand for electricity, power flow, and the index of the (SAIFI and SAIDI). This research applies the technology Sanitary Landfill to produce landfill gas (LFG) as the primary energy of WPP. In calculating the growth predictions of electricity usage in the industrial, household, public, and commercial sectors from 2017 to 2025 in APJ Surakarta, the DKL Method 3.01 is applied. ETAP 12.6 was applied to analyze the power flow in the form of power losses and voltage losses and the Section method to calculate the reliability index (SAIFI, SAIDI) before and after penetration of WPP in PLR 01 and GDO 04 of Manahan Substation, Surakarta. The results showed that Trash from 5 Regencies and Cities, WPP was able to generate a maximum power of $10.1 \mathrm{MW}$. During peak load, WPP is able to reduce electricity demand of Substation for $0.920 \%$ in 2019, $0.879 \%$ in 2020, $0.838 \%$ in $2021,0.799 \%$ in 2022, $0.760 \%$ in 2023, $0.723 \%$ in 2024, and $0.686 \%$ in 2025. The drop voltage at the tip of the feeder (No Substation Transformer BSP01005) has improved $29.4 \%$, power losses have improved 25\%, SAIFI has improved $61.36 \%$, and SAIDI has improved $29 \%$, after WPP penetration.
\end{abstract}

Keywords: Sanitary Landfill, WPP, DKL 3.01, Section Technique, ETAP

\section{Introduction}

The amount of electricity used continues to increase along with technological advancements and public welfare [1]. To meet the needs of electricity growth in an area, it requires the construction and addition of electricity generators that are Distributed Generation (DG) or centralized so that the needs and availability of electrical energy are appropriate [2].

The construction of power plants in Indonesia continues to be intensified but seen from the input of primary energy materials, power plants in Indonesia are still dominated by fossil fuels. This can be seen from Indonesian Energy Outlook, which states that coal and gas fueled plants have the highest share, namely 50\% (26 GW) and 23\% (12 GW), followed by power plants fuel oil with a share of around $14 \%(7.5 \mathrm{GW})$ [3].

The condition of fossil energy sources if it is assumed there are no new reserve discoveries, based on the R\&P (Reserve and Production) ratio in 2014, then oil will run out in 12 years, natural gas 37 years, and coal 70 years. This reserve will run out even faster than the year mentioned above because of the tendency of fossil energy production which continues to increase [4]. Therefore, the development of renewable energy is needed in order 
to reduce dependence on fossil fuels. One of the most environmentally friendly, renewable energy is the Waste Power Plant (WPP). In addition to generating energy, WPP can also overcome the problem of municipal waste that continues to accumulate.

The problem of garbage in the city of Surakarta is now an urgent agenda for the city government of Surakarta, this is caused by the capacity of the Putri Cempo landfill, which in the not too distant future is unable to accommodate the garbage from polling stations scattered in Surakarta. In addition to these factors, social and environmental factors also become a serious thing here, because the waste in the Putri Cempo landfill pollutes the environment and causes social upheaval around the landfill. Therefore, it needs continuous handling that can benefit all parties, one of the things that can be applied here is to utilize the Putri Cempo landfill waste for Waste Power Plant (WPP).

The APJ Surakarta electricity demand from year to year continues to experience growth. Electricity needs in the city of Surakarta for example, the use of electricity in 2015 increased to $45.9 \%$ in 2014 $(609,616,790 \mathrm{kWh}$ in 2014 and $889,489,500 \mathrm{kWh}$ in 2015) the growth was mostly used by the household sector which was $328,006,741 \mathrm{kWh}$ or $36.88 \%$ of total load usage. This is influenced by industrial development and population growth, which averages $0.53 \%$ per year.

Land for garbage disposal in Surakarta is currently experiencing a very serious problem. This can be seen from the capacity (TPA) of the Final Waste Disposal Site and (TPS) of the Temporary Garbage Disposal Site where the garbage has accumulated. Piles of garbage can cause environmental pollution whether air, ground water, or the beauty of the surrounding environment, but it can be overcome by making use of waste for power generation. Seen from the infrastructure aspect of the area, Suarakarta has not utilized waste as an alternative material for the energy sector or for agriculture (compost), when viewed from its application, Surakarta organic waste which is quite significant is very potential for the application of Sanitary Landfill Technology.

By utilizing waste as an alternative primary energy producer based on the potential of waste in Wonogiri, Klaten, Sukoharjo, Boyolali, Karanganyar, Sragen, and the city of Surakarta for Waste Power Generation, it is necessary to do a detailed electricity system planning so that the need for increased power can be connected to city distribution networks with optimal design results.
WPP can help supply additional power to the network. In its application, the Waste Power Plant is placed near the load [5]. With so power losses, voltage drop can be reduced to a minimum. In addition, the reliability of the system can be improved because it has the power supply from two sources (WPP and Substation). This power plant is no longer connected to the transmission network but directly to the $20 \mathrm{kV}$ distribution network. Such generating capacity is classified as middle class because of its small capacity and working voltage which is in the medium voltage network. This system is commonly referred to as Distributed generation (DG). From the research it can be analyzed the quantity of energy raised can affect the level of service and performance of the Surakarta APJ distribution network.

As for some previous studies related to this research in various applications. This can be seen in research, such as:

The growth rate of electricity use in Lamongan Regency uses the DKL 3.01 method by an average of $17.44 \%$ [6]. Implementing distributed generation in the power system can have a beneficial effect, namely: increasing reliability, eliminating investment in transmission lines, and reducing environmental impacts [7]. As for the improvement in the value of the reliability index and the reduction in large power losses by linking the DG placement to find out the best performance of DG operations. The optimal DG results are DG which is located closest to the load center and which has a greater number of customers [8].

\section{Methods}

\section{II.1. Research Procedure}

Flowchart for the research of procedure is presented in Fig. 1.

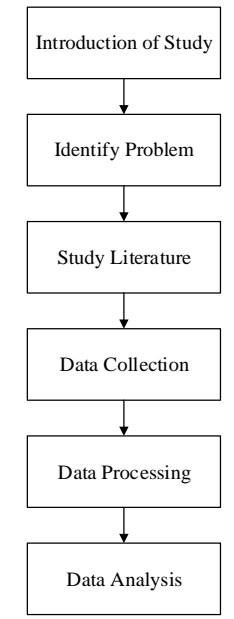

Fig. 1. Flowchart research procedure

Journal of Electrical Technology UMY, Vol. 3, No. 4 


\section{II.2. Location Research}

Activities observation on the analysis of waste utilization for electrical power generation its effect to distribution in Surakarta. The location research in Jatirejo Village RT 06, RW11, Mojosongo Village, Jebres District which has the potential to generate electricity for WPP. Fig. 2 is presented the map region of the location research in Surakarta

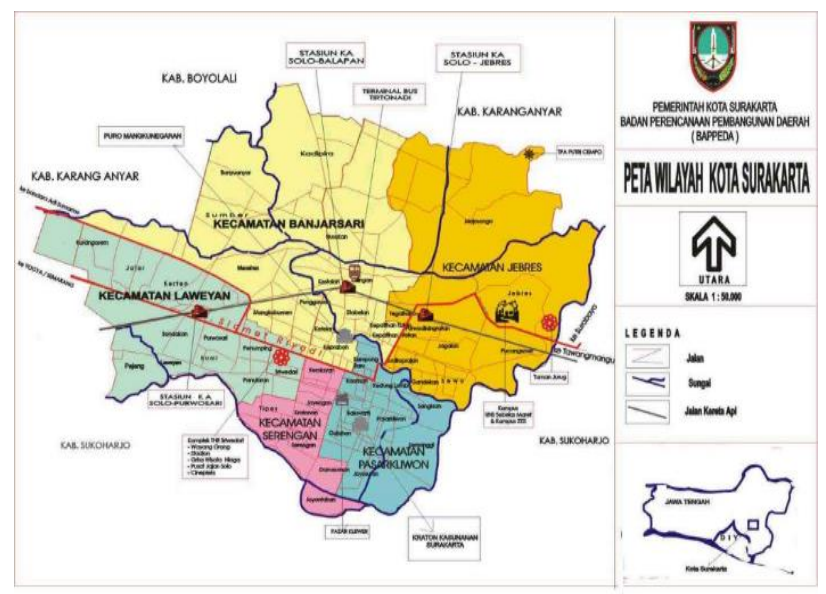

Fig. 2. Location map of Surakarta City Research

\section{II.3. Time Research}

Research time on Putri Cempo Landfill waste utilization analysis for Waste Electric Power and its effect on the network Surakarta Distribution starts from September 2016 to March 2017.

\section{II.4. Research Data Collection}

This data collection was carried out to explore the information about the state of the Putri Cempo landfill waste as a system of electricity distribution in Surakarta City. The following are the results of data collection:

1. Data Source

Data is collected in the city of Surakarta, Central Java, precisely on:

a) PT. PLN (persero) UPJ Surakarta City That is the source to get data about the electricity distribution network UPJ Surakarta.

b) Sanitation and Parks Agency (DKP) of Surakarta City.

That is the source of data regarding the potential of Jebres landfill waste for Waste Electric Power Generation (WPP).

2. Data Collection

Research data can be grouped specifically in 4 categories, namely:

a) Distribution Network data that passed through
Putri Cempo landfill (Feeder GDO 04 and PLR 010)

- Network Configuration Data

- Network Delivery Data

- Data Distribution Transformer

- Load data

- Data Loading

- One Line Data Distribution System Diagram of $20 \mathrm{kV}$

b) Data for Analysis of the Reliability of the Distribution Network on GDO 04 and PLR 01

- Protection Equipment Location Data

- Data on Number of Customers at the Load Point

- Data length or distance between Load Points

- Large data load in the past 1 week.

c) Waste Potential Data

- Data on the amount of waste per day that goes to Putri Cempo Landfill

- Waste composition data in Surakarta City

- External waste data if used to encourage greater electrical energy production.

d) Load demand data by sector

- Household sector data in the last 2 years

- Industrial sector data in the last 2 years

- Business sector data in the past 2 years

- Public sector data in the last 2 years

- Big data load factors for each sector

\section{II.5. Data Processing}

Data processing is done by linking the theoretical basis with the data obtained. Processing is done in 2 ways relevance, there is:

1. Manual calculation using relevant formulas according to the standard for estimating electrical energy from the Putri Cempo landfill waste, and using ETAP software for the analysis of electric power flow, calculating the predicted electric power demand using the DKL 3.01 Method

2. The section technique method for calculating the reliability index.

\section{II.6. Data Analysis}

Data processing is done using by ETAP software, DKL 3.01 method, and the section technique method, the results of which will be analyzed to determine the potential of biogas / methane gas used for Power Plant Waste (WPP). 


\section{Results and Discussion}

\section{III.1. The Potential of Electrical Energy from Waste in Surakarta}

To analyze and discuss the potential of electrical energy from Solo waste in The Putri Cempo Landfill, the research need some data from several valid source, so the object produces a high degree of accuracy. Trash in TPA with conventional awareness $=0.50-0.60$ tons $/ \mathrm{m}^{3}$ [5]. So, the regional weight of waste in Surakarta can be predicted based on Table I.

1. Calculation of Total Solid (TS), Volatile Solid (VS), and Biogas Production in process Anaerobic Digestion

To calculation in process Anaerobic Digestion. Equations that can used is the equation:

$$
\begin{array}{ll}
\mathrm{T}_{\mathrm{S}} & =27.7 \% \times \mathrm{Q} \\
\mathrm{M}_{\mathrm{S}} & =74.1 \% \times \mathrm{T}_{\mathrm{S}} \\
\mathrm{M}_{\mathrm{BS}} & =0.676 \times \mathrm{M}_{\mathrm{S}}
\end{array}
$$

Note:

$\mathrm{Q}=$ The amount of potential Waste In $(\mathrm{kg} /$ day)

$\mathrm{T}_{\mathrm{S}} \quad=$ Value of Total Solid In ( $\left.\mathrm{kg} / \mathrm{day}\right)$

$\mathrm{M}_{\mathrm{S}} \quad=$ Mass Volatile Solid In (kg/day)

$\mathrm{M}_{\mathrm{BS}}=$ Mass of Biogas Procurement (kg/day)

If the regional waste potential in Surakarta known by $(\mathrm{Q})$ : 523.41 Ton/day.

$$
\begin{aligned}
& \text { Therefore } \\
& \begin{aligned}
\mathrm{T}_{\mathrm{S}} & =27.7 \% \times \mathrm{Q} \\
\mathrm{T}_{\mathrm{S}} & =27.7 \% \times 523.41 \mathrm{Ton} / \text { day }=144.98 \mathrm{Ton} / \text { day } \\
\mathrm{Ms} & =74.1 \% \times \mathrm{TS} \\
& =74.1 \% \times 144.98=107.43 \mathrm{Ton} / \text { day }
\end{aligned}
\end{aligned}
$$

From the above results, we can determine the mass production of methane gas every day in Surakarta Region,

$$
\begin{aligned}
\mathrm{M}_{\mathrm{BS}} & =0.676 \times \mathrm{M}_{\mathrm{S}} \\
& =0.676 \times 107.43 \mathrm{Ton} / \mathrm{day}=72.63 \text { Ton } / \text { day }
\end{aligned}
$$

2. Calculation of Amount of Methane Gas Produced $\mathrm{M}_{\mathrm{GM}}=60 \% \times \mathrm{M}_{\mathrm{BS}}$

Note:

$\mathrm{M}_{\mathrm{GM}}=$ Mass of methane gas ( $\mathrm{kg} /$ day)

$\mathrm{M}_{\mathrm{BS}}=$ Mass of biogas production ( $\mathrm{kg} /$ day)

Known Mass of Biogas Production (MBS)

$$
\begin{aligned}
& =72.63(\text { Ton/day }) \\
M_{\mathrm{GM}} & =60 \% \times \mathrm{M}_{\mathrm{BS}} \\
& =60 \% \times 72.63 \mathrm{Ton} / \mathrm{day}=43.58 \mathrm{Ton} / \mathrm{day}
\end{aligned}
$$

So, the mass production of methane gas from biogas is 66.68 Ton/day.

3. Amount of Energy Generated from Methane Gas

In this case, to use of a Gas Turbine Power Plant (Electricity Generation) because the cost and capacity of the power generated is also quite large. In its application, ordinary gas turbines are used for power capacities of $1 \mathrm{MW}$ to $100 \mathrm{MW}$. Data of energy conversion presented in Table II.

TABLE I

Average of Volume $\left(\mathrm{M}^{3}\right)$ And Weight (Ton) Daily Waste for Regency/City of SuRAKarta Regional

\begin{tabular}{ccccc}
\hline \hline \multirow{2}{*}{ District/City } & $\begin{array}{c}\text { Mixed Waste } \\
\text { Volume }\left(\mathrm{m}^{3}\right)\end{array}$ & $\begin{array}{c}\text { Weight of Mixed Waste } \\
\left(1 \mathrm{~m}^{3}=0,57 \text { Ton }\right)\end{array}$ & $\begin{array}{c}\text { Waste Composition } \\
\text { Org. }(\%)\end{array}$ & $\begin{array}{c}\text { Weight of Waste } \\
\text { Org. (Ton) }\end{array}$ \\
\hline Karanganyar & 315.00 & 179.55 & 63 & 113.12 \\
Boyolali & 70.37 & 40.11 & 70 & 28.08 \\
Sragen & 180.00 & 102.60 & 75 & 76.95 \\
Sukoharjo & 250.00 & 142.5 & 80 & 114.00 \\
Klaten & 150.00 & 85.5 & 65 & 55.77 \\
Wonogiri & 199.00 & 113.43 & 41 & 46.51 \\
Surakarta City & 252.00 & 143.64 & 61.95 & 88.98 \\
\hline \multicolumn{5}{c}{ Total Mass of Organic Waste (Q) (Ton/Day) } \\
\hline \hline
\end{tabular}

TABLE II

DATA OF ENERGY CONVERSION

(Source: Sulistyo, 2010)

\begin{tabular}{cc}
\hline \hline Components & Losses $(\mathrm{kW})$ \\
\hline $1 \mathrm{Kg}$ of Methane Gas & $6.13 \times 10^{7} \mathrm{~J}$ \\
$1 \mathrm{kWh}$ & $3.6 \times 10^{6} \mathrm{~J}$ \\
$1 \mathrm{~m}^{3}$ Methane Gas & $9.39 \mathrm{kWh}$ \\
\hline \hline
\end{tabular}


Known the Value of :

$\mathrm{V}_{\mathrm{GM}}=43.58$ Ton/day

Energy production $(\mathrm{J} / \mathrm{h})=43.58 \times 6.13 \times 10^{7}$

$$
\begin{aligned}
& =267.15 \times 10^{10} \mathrm{~J} / \text { day } \\
\text { Power Production } & =\frac{267.15 \times 10^{10}}{3.6 \times 10^{6} \times 24} \\
& =3.03 \times 10^{4} \mathrm{~kW}
\end{aligned}
$$

In some observation, the amount of power that can be generated by gas turbine is $24 \%-35 \%$ of the potential waste power. In this study the authors apply a $30 \%$ efficiency value, so we can determine the following power:

$$
\begin{aligned}
\mathrm{P} & =30 \% \times \text { Power Production Before Awakened } \\
& =30 \% \times 30.3 \mathrm{MW} \\
& =10.1 \mathrm{MW}
\end{aligned}
$$

So the power that can be generated by turbine gas is $10.1 \mathrm{MW}$.

\section{III.2. The Effect of the Waste Power Plant on the Estimated Growth in Electricity Demand}

The next step is to analyze the growth of electricity demand in this case, the authors apply the DKL 3.01 method, which is a method based on sector of energy use (public, industrial, commercial, household).

1. Load Growth Estimation (2017 - 2026) Using

DKL 3.01 Method

The estimate load growth estimation (2017 2026) using DKL 3.01 method is presented by number of customers and total sold energy. Table III shown of number of customers Surakarta and
Table IV shown of total sold energy.

2. Growth of Electrical Energy Needs of Surakarta APJ Services

Based on the population in the Regency / City of the APJ Surakarta service area and its growth each year, it can be predicted the population in the following year. Equations that can used is the equation 1 :

$$
\mathrm{P}_{\mathrm{t}}=\mathrm{P}_{\mathrm{t}-1}\left(1+\Delta_{\mathrm{t}-1}\right)
$$

Note:

$\mathrm{Pt}=$ large population predicted in year $\mathrm{t}$

Pt-1 = large population predicted in year $\mathrm{t}-1$

$\Delta \mathrm{t}-1=$ predicted population growth before year $\mathrm{t}$ $(\%)$

3. Prediction of the Use of Electrical Energy in the Household Sector

Predictions of electricity growth in the household sector can use the following equation 2 .

$$
\mathrm{E}_{\mathrm{RT}}=\text { Pel. Rt } \times \mathrm{UKR}_{(\mathrm{t}-1)}
$$

Note:

$\mathrm{E}_{\mathrm{RT}}=$ amount of household energy consumption in year $\mathrm{t}$

Pt-1 = number of household customers in year $\mathrm{t}$

$\Delta \mathrm{t}-1=$ average size of electricity consumption $(\%)$.

For the calculation of predictions of household energy use in 2019 to 2025 using the same steps and steps. Fig. 3 is presented customer predictions and the use of public sector electricity from 2017 to 2025.

TABLE III

CUSTOMERS OF APJ SURAKARTA

(SOURCE : PLN APJ SURAKARTA, 2016)

\begin{tabular}{cccccc}
\hline \hline Year & House-hold & Public & Industrial & Commercial & $\begin{array}{c}\text { Electrification } \\
\text { Ratio (\%) }\end{array}$ \\
\hline 2015 & $1,139,681$ & 48,117 & 1,336 & 31,924 & - \\
2016 & $1,170,900$ & 53,681 & 1,461 & 33,414 & 95.91 \\
\hline \hline
\end{tabular}

TABLE IV

TOTAL SOLD ENERGY (KWH)

(SOURCE : PLN APJ SURAKARTA, 2016)

\begin{tabular}{cccccc}
\hline \hline Year & House-hold & Public & Industrial & Commercial & Total \\
\hline 2015 & $1,439,308,441$ & $444,992,403$ & $487,996,012$ & $240,385,290$ & $4,372,463,184$ \\
2016 & $1,529,355,279$ & $487,996,012$ & $2,375,092,098$ & $265,824,580$ & $4,645,301,072$ \\
\hline \hline
\end{tabular}




\section{Sold Energy in Household}

\section{$(\mathrm{kWh})$}

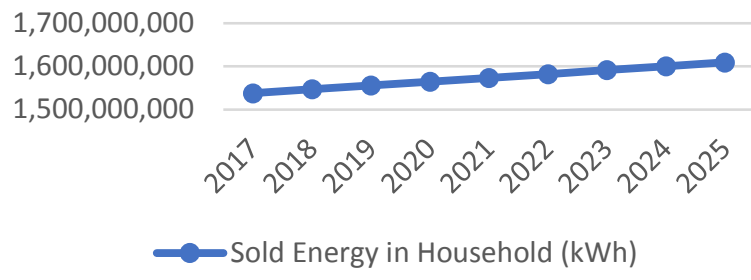

Fig. 3. Graph of growth prediction for the use of electricity in the household sector

4. Prediction of the Use of Electrical Energy in the Commercial Sector

Predictions of electricity growth in the commercial sector can use the following equation 3 .

$$
\mathrm{EPt}=[\mathrm{EPt}-1(1+\mathrm{Gt})]
$$

Where are the parameters used:

- Large number of household customers (Rt Cust)

- Large number of commercial customers (K Cust)

- Comparison of commercial customers to household customers (RPK)

- The growth rate of commercial sector electricity use (Gt)

For the calculation of predictions of commercial energy use in 2019 to 2025 using the same steps and steps. Fig. 4 is presented customer predictions and the use of public sector electricity from 2017 to 2025.

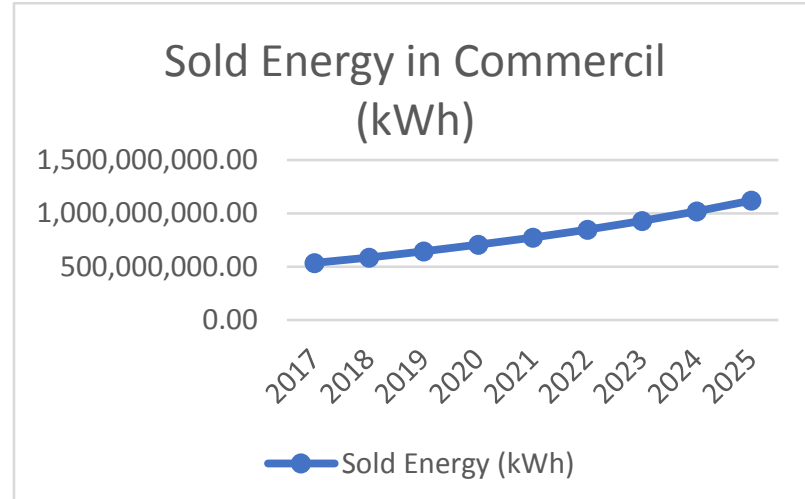

Fig. 4. Graph of growth prediction for the use of electricity in the commercil sector

5. Prediction of the Use of Electrical Energy in the Industry Sector

Predictions of electricity growth in the industry sector can use the following equation 4 .

$$
\mathrm{EI}_{\mathrm{t}}=\left[\mathrm{EI}_{\mathrm{t}-1}\left(1+\frac{G t . e 1}{100}\right)\right.
$$

Calculation of the estimated electrical energy needs of industrial sector customers is done using parameters.

- Number of industrial customers (It Cust)

- Growth rate of GRDP in the industrial sector (Gt)

-Value of customer elasticity in the industrial sector (ei)

For the calculation of predictions of industry energy use in 2019 to 2025 using the same steps and steps. Fig. 5 is presented customer predictions and the use of public sector electricity from 2017 to 2025.

\section{Sold Energy in Industry (kWh)}

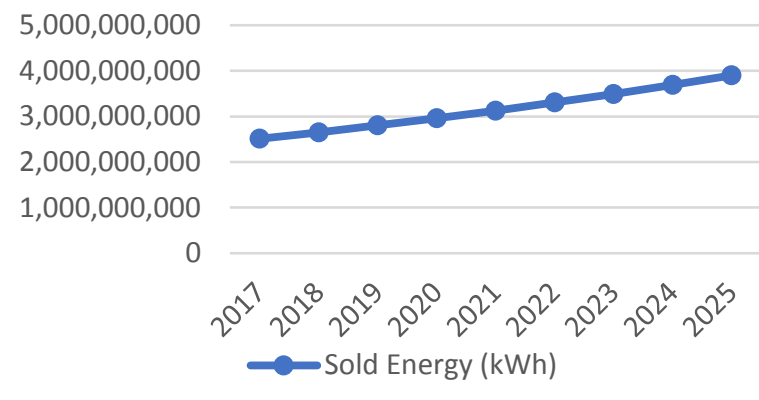

Fig. 5. Graph of growth prediction for the use of electricity in the industry sector

6. Prediction of the Use of Electrical Energy in the Public Sector

Predictions of electricity growth in the public sector can use the following equation 5 .

$$
\mathrm{EP}_{\mathrm{t}}=\left[\mathrm{EP}_{\mathrm{t}-1}\left(1+\mathrm{G}_{\mathrm{t}}\right)\right]
$$

Note:

$\mathrm{E}_{\mathrm{PT}}=$ amount of public energy consumption in year $\mathrm{t}$

Gt = The growth rate of commercial sector electricity use

For the calculation of predictions of public energy use in 2019 to 2025 using the same steps and steps. Fig. 6 is presented customer predictions and the use of public sector electricity from 2017 to 2025 . 
Sold Energy in Public Sector (kWh)

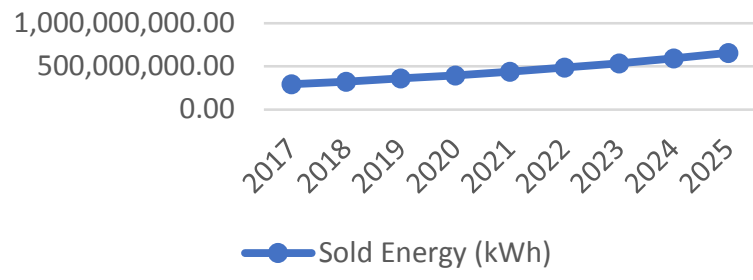

Fig. 6. Graph of Growth Prediction for the Use of Electricity in the Public Sector

7. The Number of Total Customer Predictions and Electricity Consumption

To determine amount of customer can use the following equation 6 .

$$
\text { Pel.Tt }=\text { Pel.Rt }+ \text { Pel.Kt }+ \text { Pel.It }+ \text { Pel.Pt }
$$

Note:

Pel. $\mathrm{Tt}=$ Large number of total customers

Pel. Rt = Large number of household customers

Pel. Kt = Large number of commercial customers

Pel. It = Large number of industry customers

Pel. Pt = Large number of public customer

For the calculation of predictions of total customers in one year for all sector use in 2019 to 2025 using the same steps and steps. Fig. 7 is presented customer predictions and the use of public sector electricity from 2017 to 2025.

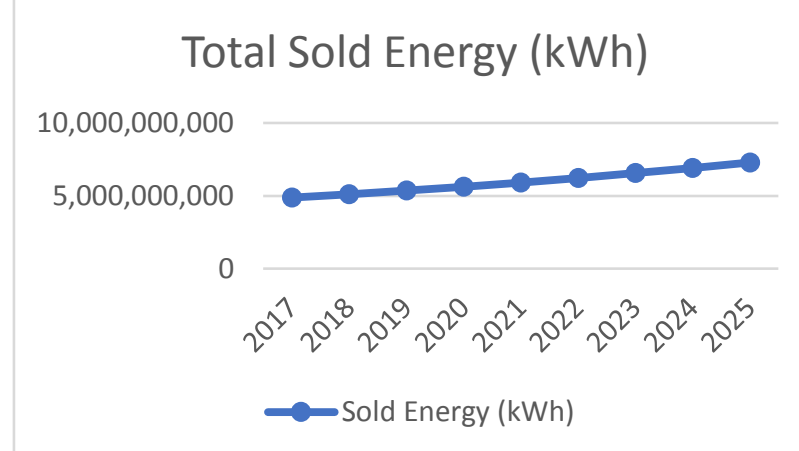

Fig. 7. Estimated graph of total electric energy usage

8. Forecasting the Growth of Peak Loads

To analyze the growth of electrical energy for analysis peak load is needed in order to increase energy supply to the network. For the forecasting of peak loads can be used the following equation 7 .

$$
\mathrm{BPt}=\frac{E P t}{8760 \times L F t}
$$

Note:

$\mathrm{BPt}=$ large of peak load in $\mathrm{t}$ year

$\mathrm{EPt}=$ large amount of energy production in $\mathrm{t}$ year

$\mathrm{LFt}=$ large of load factor in $\mathrm{t}$ year

For the calculation of predictions of peak loadin one year for all sector use in 2019 to 2025 using the same steps and steps. Fig. 7 is presented customer predictions and the use of public sector electricity from 2017 to 2025.

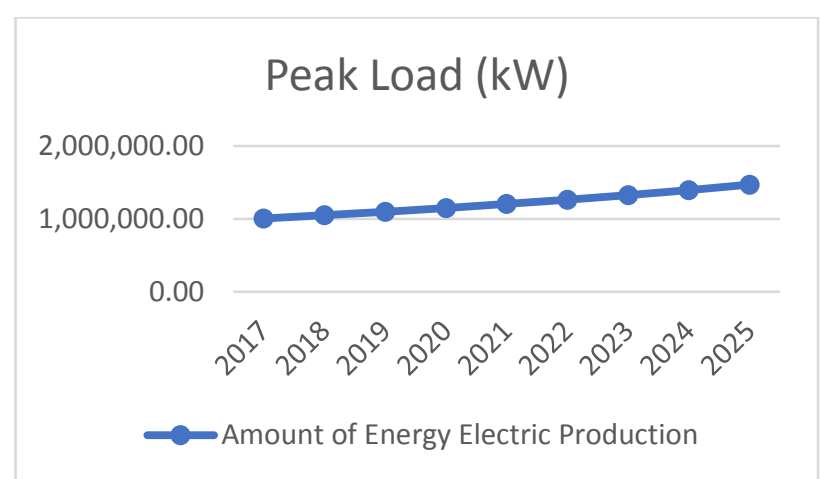

Fig. 8. Graph of APJ peak load estimates in Surakarta

9. The Effect of the Application of WPP to the Projected Growth in Electricity Demand During Peak Load on Substation in APJ Surakarta

The addition of WPP in APJ Surakarta distribution network, it affects for power supply to Substation. If assumed the WPP operated and connected to the distribution in 2019, the effect is presented by Table V and the graphic by Fig. 9.

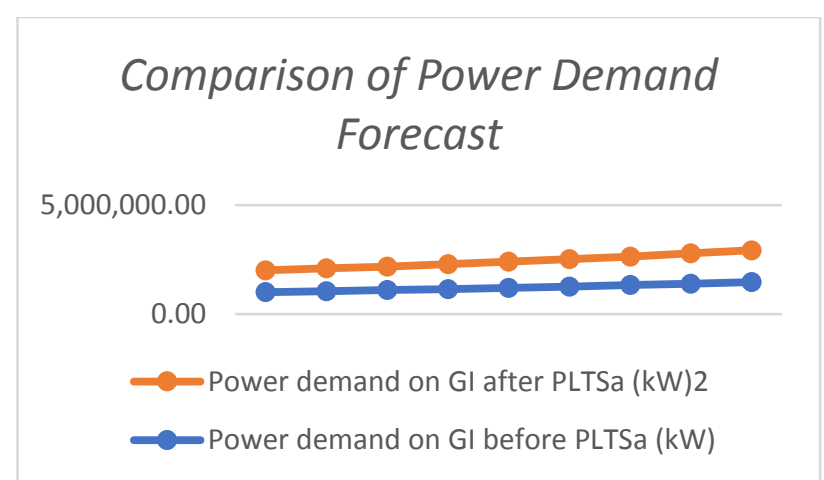

Fig. 9. Graphic comparison of power demand forecast from substation before and after implementation (WPP) in APJ Surakarta

A decrease for the value of the percentage of demand power from Substation to WPP, due the factor of increasing demand for electricity in Surakarta every year, while the electrical energy produced by WPP is the same. 
TABLE V

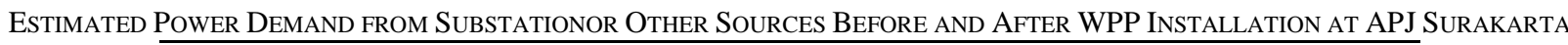

\begin{tabular}{cccc}
\hline \hline Year & Power demand before WPP & Power demand after WPP & $\begin{array}{c}\text { The Effect of WPP on } \\
\text { Reducing Electricity } \\
\text { Demand from } \\
\text { SUBSTATION(\%) }\end{array}$ \\
\hline 2017 & $1,004,966.10$ & $1,004,966.10$ & 0 \\
2018 & $1,049,750.29$ & $1,049,750.29$ & 0 \\
2019 & $1,097,775.54$ & $1,087,675.54$ & 0.920 \\
2020 & $1,149,303.38$ & $1,139,203.38$ & 0.879 \\
2021 & $1,204,618.11$ & $1,194,518.11$ & 0.838 \\
2022 & $1,264,028.88$ & $1,253,928.88$ & 0.799 \\
2023 & $1,327,872.13$ & $1,317,772.13$ & 0.760 \\
2024 & $1,396,513.88$ & $1,386,413.88$ & 0.723 \\
2025 & $1,470,352.75$ & $1,460,252.75$ & 0.686 \\
\hline \hline
\end{tabular}

\section{III.3. The Effect of WPP Installation on the} Reliability Index of the GDO 04 and PALUR 01 Feeder Distribution Networks Manahan

1. Calculation and Analysis of Reliability Index of GDAN 04 Manahan Electric Power Distribution Network Without DG (WPP)

Based on data of channel length, load amount, channel reliability index and equipment failure then the distribution network reliability index is evaluated when and without penetration DG (WPP) GDO 04 and PLR 01 feeders. Data needed for the evaluation of the distribution network reliability index (network configuration, length of each channel, number of SPLN subscribers about index calculation standards reliability) is used as a basis for evaluating each Section of the network which is then integrated with other sections.

The reliability index values (SAIDI and SAIFI) prior to the DG application can be determined by adding up the number of SAIDI for all sections and SAIFI for all sections. SAIFI is calculated by adding up the total value of SAIFI section 1 to section 5. SAIDI is calculated by adding up the total value of SAIDI section 1 to section 5. The values can be seen in Table VI.

TABLE VI

RELIABILITY INDEX (SAIFI AND SAIDI) FEEDER GDO 04 AND PALUR 01 WITHOUT WPP

\begin{tabular}{ccc}
\hline \hline \multirow{2}{*}{ No. Section } & \multicolumn{2}{c}{ System Reliability Index } \\
\cline { 2 - 3 } & $\begin{array}{c}\text { SAIFI } \\
\text { (Fail/year) }\end{array}$ & $\begin{array}{c}\text { SAIDI } \\
\text { (Hour/Year) }\end{array}$ \\
\hline 1 & 0.49577 & 0.77703 \\
2 & 0.37709 & 1,06346 \\
3 & 0.37709 & 0.35283 \\
4 & 0.46065 & 0.93851 \\
5 & 0.42083 & 0.51809 \\
\hline Total & 2.13142 & 3.64992 \\
\hline \hline
\end{tabular}

So, for the feeders analyzed, the SAIFI score was 2.13142 times/year and the SAIDI value was 3.64992 hours/year.

2. Calculation and Analysis of Reliability Index of GDAN 04 Manahan Electric Power Distribution Network With DG (WPP)

The reliability index values (SAIDI and SAIFI) when after the DG application can be determined by adding up the number of SAIDI for all sections and SAIFI for all sections. SAIFI is calculated by adding up the total value of SAIFI section 1 to section 5. SAIDI is calculated by adding up the total the total SAIDI values in section 1 through section 5 . The values can be seen in Table VII.

TABLE VII

RELIABILITY INDEX (SAIFI AND SAIDI) FEEDER GDO 04 AND PALUR 01 WITH WPP

\begin{tabular}{ccc}
\hline \hline \multirow{2}{*}{ No. Section } & \multicolumn{2}{c}{ System Reliability Index } \\
\cline { 2 - 3 } & $\begin{array}{c}\text { SAIFI } \\
\text { (Fail/year) }\end{array}$ & $\begin{array}{c}\text { SAIDI } \\
\text { (Hour/Year) }\end{array}$ \\
\hline 1 & 0.23880 & 0.73850 \\
2 & 0.25046 & 0.26572 \\
3 & 0.05472 & 0.16928 \\
4 & 0.29475 & 0.91360 \\
5 & 0.15260 & 0.47799 \\
\hline Total & 0.99132 & 2.56509 \\
\hline \hline
\end{tabular}

So, for the feeders analyzed, the SAIFI score was 0.99132 times/year and the SAIDI value was 2.56509 hours/year. Based on using the section technique method, we can see the reliability index comparison between before and after the application of DG (WPP). After the DG (WPP) is installed, it turns out to be very effective in improving the quality of the reliability index, as presented in Table VIII. 
TABLE VIII

COMPARISON OF RELIABILITY INDEX (SAIFI AND SAIDI) FEEDER GDO 04 AND PALUR 01 BEFORE AND AFTER WPP INSTALLATION

\begin{tabular}{ccccc}
\hline \hline & \multicolumn{4}{c}{ System Reliability Index } \\
\cline { 2 - 5 } No. & \multicolumn{2}{c}{ SAIFI } & \multicolumn{2}{c}{ SAIDI } \\
\cline { 2 - 5 } Section & Non WPP & WPP & Non WPP & WPP \\
\cline { 2 - 5 } & 0.49577 & 0.23880 & 0.77703 & 0.73850 \\
1 & 0.37709 & 0.25046 & 1.06346 & 2.56509 \\
2 & 0.37709 & 0.05472 & 0.35283 & 0.16928 \\
3 & 0.46065 & 0.29475 & 0.93851 & 0.91360 \\
4 & 0.42083 & 0.15260 & 0.51809 & 0.47799 \\
5 & 2.56509 & 0.99132 & 3.64992 & 2.59052 \\
\hline Total & & & & \\
\hline \hline
\end{tabular}

So the value of SAIDI and SAIFI experienced a significant improvement, this can be seen from the table and figure above which states that, SAIFI (System Average Interruption Frequency Index) before WPP penetration is 2.56509 Disturbances / year after WPP penetration, SAIFI becomes 0.99132 disturbances/year or experiencing improvement 61.36\%. SAIDI (System Average Interruption Duration Index) before WPP penetration was 3.64992 hours/year and after WPP penetration, SAIDI became 2.59052 hours/year or experienced a $29 \%$ improvement. This happens because before the DG is applied, the feeder is radially configured and after the DG application the feeder is interconnected.

\section{Conclusion}

From the research that has been done, the following conclusions are obtained:

1. With organic waste 523.41 tons/day from the garbage dump in Surakarta, Karanganyar, Sukoharjo, Boyolali, Wonogiri Regency, Sragen and Klaten. WPP is able to generate a maximum power of 10.1 MW.

2. The penetration of WPP in the electricity distribution network has an impact on the growth of electricity demand at the substation in APJ Surakarta from 2019 to 2025. During peak loads, WPP is able to reduce the demand for electrical power from SUBSTATION $0.920 \%$ in 2019, $0.879 \%$ in the year 2020, $0.838 \%$ in 2021, $0.799 \%$ in $2022,0.760 \%$ in the year 2023 , $0.723 \%$ in 2024 and $0.686 \%$ in 2025 .

3. The Waste Power Plant (WPP) has a significant effect on the improvement of the reliability index of the Fedeer GDO 04 and PLR 01 electricity distribution network systems.
a. SAIFI (System Average Interruption

Frequency Index) prior to WPP penetration was 2.56509 disturbances/year after WPP penetration, SAIFI became 0.99132 disturbances/year or experienced an improvement of $61.36 \%$.

b. SAIDI (System Average Interruption Duration Index) before WPP penetration was 3.64992 hours/year and after WPP penetration, SAIDI became 2.59052 hours/year or experienced a $29 \%$ improvement. From the five test conditions of the propulsion system on KRL it can be seen that the smallest losses with the greatest efficiency are in the test conditions.

\section{Acknowledgements}

This work was supported by Universitas Muhammadiyah Yogyakarta.

\section{References}

[1] Allen Short, T. 2014. Electric Power System Distribution Handbook Second Edition. USA: CRC Press.

[2] IEEE Std. 1366-2012. 2012. IEEE Guide for Electric Power Distribution Reliability Indices. USA.

[3] A. Samir, Elsagheer Mohamed, "Smart Street Lighting Control and Monitoring System for Electrical Power Saving by Using VANET", Int. J. Communications Network and System Sciences, vol. 6, pp. 351-360, 2013.

[4] E. Damanhuri and T. Padmi, Diktat Kuliah Pengelolaan Sampah TL-3104. Bandung: Program Studi Teknik Lingkungan ITB.

[5] O. E. Indonesia, "Pengembangan Energi untuk Mendukung Industri Hijau," presented at the Delivered at the National Technology Congress, 2016.

[6] V. Vebrianto, "Studi Pengembangan serta Penyusunan Rencana Energi dan Kelistrikan Daerah dengan Memanfaatkan Potensi Energi Daerah Di Kabupaten Lamongan Jawa Timur," Skripsi, Institut Teknologi Sepuluh Nopember, Surabaya, 2009.

[7] P. D. Seribu, "Pengaruh Distributed Generation terhadap Keandalan Sistem Distribusi," Thesis, Universitas Gadjah Mada, Yogyakarta.

[8] I. M. G. Nusaman and S. H. Hartati, "Analisis Pengaruh Interkoneksi Distributed Generation (WPP Suwung) Terhadap Rugi-Rugi Daya dan Keandalan pada Penyulang Serangan," Jurnal Teknik Elektro, vol. 14(2), pp. 27-33. 


\section{Authors' information}

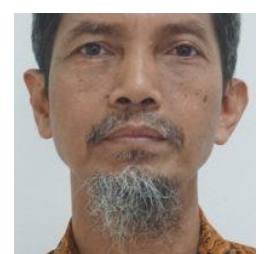

Slamet Suripto obtained his B.Eng. in Electrical Engineering from Universitas Gadjah Mada, Indonesia in 1987. His Master study was done at the Electrical Engineering, Universitas Gadjah Mada, Indonesia. He currently is a lecture in department of electrical engineering, Universitas Muhammadiyah Yogyakarta.

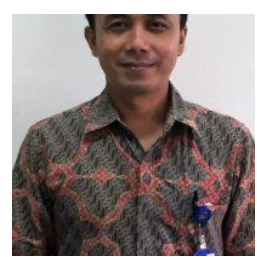

Rahmat Adiprasetya Al Hasibi obtained his B.Eng. in Electrical Engineering from Universitas Gadjah Mada, Indonesia in 2001. His Master study was done at the Electrical Engineering, Universitas Gadjah Mada, Indonesia. He currently is a lecture in department of electrical engineering, Universitas Muhammadiyah Yogyakarta.

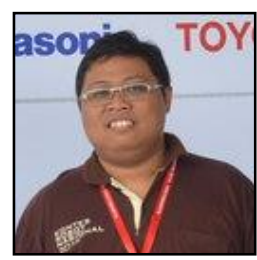

Rama Okta Wiyagi obtained his B.Eng. in Electrical Engineering from Universitas Muhammadiyah Yogyakarta, Indonesia in 2009. His Master study was done at 2015 at the Electrical Engineering, Universitas Gadjah Mada, Indonesia. He currently is a lecture in department of electrical engineering, Universitas Muhammadiyah Yogyakarta.

Sanupal obtained her B.Eng. in Electrical Engineering from Universitas Muhammadiyah Yogyakarta, Indonesia in 2018.

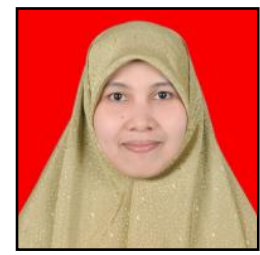

Yessi Jusman obtained her B.Eng. in Electrical and Electronic Engineering from Andalas University, Indonesia in 2007. She worked as a Research Assistant started in July 2008 until November 2009 in Universiti Sains Malaysia. Her Master study was done at 2012 at the School of Electrical and Electronic Engineering, USM Engineering Campus in Nibong Tebal, Penang, Malaysia. She was finished her $\mathrm{PhD}$ degree at 2016 with specializes in Image, Signal Processing, and algorithms.

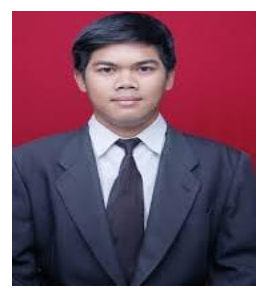

Didik Aribowo obtained his M.Eng. in Electrical Engineering from Institut Teknologi Sepuluh Nopember, Surabaya, Indonesia in 2013. He currently is a lecture in Vocational Education of Electrical Engineering Department, Universitas Sultan Ageng Tirtayasa, Banten, Indonesia. His research interests are in control system, electronics, and instrumentation. 